\title{
Territorial Conflicts in the Contemporary Indian Novel in English
}

\section{Angelo Monaco}

\section{(2) OpenEdition \\ 12 Journals}

Electronic version

URL: https://journals.openedition.org/ces/4723

DOI: $10.4000 /$ ces.4723

ISSN: 2534-6695

\section{Publisher}

SEPC (Société d'études des pays du Commonwealth)

\section{Printed version}

Date of publication: 1 September 2016

Number of pages: 11-21

ISSN: 2270-0633

\section{Electronic reference}

Angelo Monaco, "Territorial Conflicts in the Contemporary Indian Novel in English", Commonwealth Essays and Studies [Online], 39.1 | 2016, Online since 05 April 2021, connection on 19 June 2021. URL: http://journals.openedition.org/ces/4723 ; DOI: https://doi.org/10.4000/ces.4723

Licence Creative Commons

Commonwealth Essays and Studies is licensed under a Licence Creative Commons Attribution - Pas d'Utilisation Commerciale - Pas de Modification 4.0 International. 


\section{Territorial Conflicts in the Contemporary Indian Novel in English}

A number of contemporary Indian novels in English, such as The Lowland, The Inheritance of Loss and Can You Hear the Nightbird Call?, explore territorial conflicts in recent Indian history. Combining realist modes with postcolonial allegories, these novels offer a glimpse of gloomy post-Partition upheavals, such as the Naxal riots, the separatist movements for Gorkhaland and the Emergency, highlighting the ethical power of transnational fiction.

They know they're a nation because they've drawn their borders with blood. War is their religion. That's what it takes to make a country. Once that happens people forget they were born this or that, Muslim or Hindu, Bengali or Punjabi: they become a family born of the same pool of blood. That is what you have to achieve for India, don't you see? (Ghosh 76)

The dawn of the third millennium has witnessed the emergence of new voices in Indian fiction in English, which has become "one of the largest English-language book markets in the world" (Sen and Roy 15). With a range of themes extending from historical pan-Indian conflicts to neocolonial and global problematics, twenty-first century Indian authors writing in English foreground socio-cultural concerns specific to India in a transnational direction: they speak of sites both within and outside India which generate a mutually transformative exchange. Following Pramod K. Nayar and Bill Ashcroft, I suggest that contemporary Indian writing in English has taken a transnational turn since "Indian characters occupy multiple national and cultural spaces" (Nayar 17). These characters negotiate between old and new homes, following a "utopian supra-nationalist vision of India" (Ashcroft 30) with ethical implications. The transformative power of transnational Indian writing in English calls for connectivity and solidarity in a world which still records ethnic, religious and cultural conflicts. Contemporary texts perform ethical acts of memories which try to build up an ethics of coexistence beyond differences.

In an article published in The New York Times in 2000, Mervyn Rothstein employed the phrase "Midnight's Grandchildren" to describe contemporary writers of Indian descent who have supposedly benefited from Salman Rushdie's literary ascendancy. The list includes writers of South Asian origin living mainly in the West, such as Jhumpa Lahiri, Kiran Desai, Chitra Divakaruni, and Akhil Sharma. In the wake of Rushdie's seminal novel Midnight's Children (1981) and following his magic realist trajectories and postcolonial allegories, this new generation of writers has taken a realist turn with a focus on the political and social questions which mark the controversial scenario of recent Indian history. Unlike Rushdie who privileges epic scale narratives, these "Midnight's heirs" (Ashcroft 2014) tend to opt for transnational encounters between local stories and global perspectives, dealing with the ways borders have continuously been reshaped within erstwhile colonial territories in the light of acute ethnic and/or religious conflicts. Like "transnational parasites" (Nayar 24), these writers dwell at the intersections of two worlds, longing for a sense of "home in the world" (Ashcroft 38).

The main theme of contemporary Indian writing in English remains the painful and enduring legacies of Partition. The "long shadow of Partition" (Butalia) did not only entail a disruptive fragmentation of the former British Indian Empire, but also a 
historical catastrophe with bleak consequences. In the aftermath of 1947, the Indian subcontinent was swept by tides of communal violence which have accompanied further small-scale partitions. Memories of Partition and of its enduring tensions continue therefore to inspire writers, even when they did not directly experience the brutality of the event. Loss, trauma, alienation, and dislocation are documented in the narratives of writers who have focused on such memories of upheaval and tensions. By exploring historical frictions and by recollecting and rescuing memories from slipping into the realm of negligence, literature helps fill in the gaps, allowing us to understand the emotional and ethical impact of these events.

As the old Mayedebi in Amitav Ghosh's The Shadow Lines points out, while describing English people to her grandson, conflicts and wars are inescapable traumas required to make a country and build up a sense of identity. The common thread that runs throughout the novels discussed here - Jhumpa Lahiri's The Lowland (2013), Kiran Desai's The Inheritance of Loss (2006), and Anita Rau Badami's Can You Hear the Nightbird Call? (2006) - lies in the portrayal, more or less incidentally, of the abuse and torture which have marked Indian history in the aftermath of 1947. These novels investigate violence and conflicts generated by the need to draw boundaries in the Indian subcontinent, perpetuating divisions and geopolitical reconfigurations. Lahiri's novel deals with the Maoist revolution of the Naxalites, which engulfed West Bengal in the late 1960s. The Inheritance of Loss is set against the backdrop of the Gorkhaland movement, a violent mid-1980s uprising claiming a new independent state for an enclave comprising parts of Nepal, Bhutan, West Bengal, and the Himalayan region. Badami's novel, finally, traces the joint vicissitudes of three Indian women between India and Canada, while conflicts and troubles, such as the Emergency (1975-1977), generate chaos and devastation.

In contrast to diasporic writing which is set against binary oppositions (centre/periphery, dislocation/relocation), transnational literature resists the "from-to tension" (Nayar 18). As Nayar maintains, diasporic fiction is concerned with a linear progression from the "old" to the "new," while transnational writing suggests multiplicity and hybridization. Transnational novels incorporate the Indian past within the socio-political transformations of the contemporary world order. In an era of increased global migrancy for better job opportunities, contemporary Indian writing in English weaves local and global questions as fundamental facets of individual, familial and national changes of our fluid modernity. While some Indian novels in English explore nationbuilding or history-making events, my case studies address the preservation of boundaries and secondary divisions. Unlike the detailed historical realism we find in Rohinton Mistry's A Fine Balance (1995) on the Emergency or Rushdie's historiographic metafiction and myth-making style, the novels analyzed here do not interrogate national unity. Following a tendency pioneered by Arundhati Roy in The God of Small Things (1997), where little narratives are preferred to grand histories, the territorial insurgencies described in these fictional representations are contained in regional borders, showing the interface between local and transnational issues which cut across the ethnic borders of India. These works convey the controversial fusion of governmental and bureaucratic corruption, with a focus on neglected stories and oppressed people.

Contemporary Indian writing in English gives a pluralistic and global perspective to the idea of historical reality in postcolonial India, where territorial conflicts and marginal 
positions are persistent claims against unity and coexistence. Through a careful balance of reality and representation, Lahiri, Desai and Badami present realism as a mode which reframes the temporal continuities of colonialism within the global scenario. Their plots, characters and narrative focalizations are different from Rushdie's metafiction or the social realism of pre-Partition Indian novels, in the style of Mulk Raj Anand ${ }^{1}$ for instance. This "new" social realism bears the traces of self-reflexivity and postcolonial allegory. Having inherited a legacy of realist and magical realist characteristics, contemporary Indian writing in English tends to mingle realist modes with symbolic elements. The "new" realist wave of contemporary Indian writing in English does not reconstruct a past reality; it rather "projects interpretations of the past" (Dalley 10), creating a dialogue between personal stories and archival sources. In this sense, realism is not opposed to the surreal elements featured in Rushdie's literary works. Contemporary Indian writing in English does not imitate reality: with an emphasis on plausibility, fiction becomes a source of a postcolonial realism which offers "an ethico-political and aesthetic response to the cultural significance of history in societies established on the basis of colonial occupation" (Dalley 9-10). Contemporary Indian writing in English, therefore, re-engages postcolonial allegory, infusing it with social realism and social critique.

\section{Between Calcutta and Rhode Island: Naxalism and Migrancy in Jhumpa Lahiri's The Lowland}

The Naxalite riots erupted in the village of Naxalbari, West Bengal, in 1967. Here, the leaders of the local Communist Indian Party (belonging to the Maoist faction) started to support the revolts by agricultural laborers against local landlords. The main objective of this "annihilation campaign" was "to smash the feudal authority in the villages and to replace it by the authority of the peasants" (Dasgupta 174). The conflict gradually expanded to other Indian areas whose economy was mainly based on farming and agriculture, such as the eastern and southern states where rural feudal systems prevailed. The expansion of the riots was firmly opposed by the West Bengal communist cabinet, while on the streets and on college campuses demonstrations broke out in defense of peasants and against the violent slaughter of insurgents by governmental police. The Lowland features Udayan Mitra, a fervent revolutionary who embraces ideals and even weapons in order to fight for the independence of West Bengal and for the rights of local peasants. While his brother Subhash is more compliant to rules and moves to Rhode Island to study oceanographic chemistry, Udayan reads Felix Green, Rousseau and Marx. Through him, Jhumpa Lahiri depicts the typical revolutionary hero who questions the status quo, pursuing a new ideal order based on purity and transcendence. For Udayan, "Naxalbari is an inspiration. It's an impetus for change" (Lahiri 23). Udayan's father, by contrast, perceives the militant rhetoric of the Maoist propaganda as meaningless and empty, while his son becomes gradually enmeshed in its ideals. Mr. Mitra, who claims that his generation had striven in order to achieve independence, is the spokesman for the Nehruvian ${ }^{2}$ principle of unity and secularism and, being a government employee, he disapproves of the initiatives of the United Front.

1. Mulk Raj Anand (1905-2004) was one of the fathers of Indian fiction in English. His works deal with poverty and exploitation in Indian lower classes.

2. Jawaharlal Nehru (1889-1964) was the first Indian Prime Minster of independent India from 1947 to 1964 . His inaugural speech "Tryst with Destiny” addressed the issues of unity, freedom, and democracy. 
Being identical in their appearance and born just fifteen months apart, Subhash and Udayan look so similar that they are continually mistaken one for the other. When secondary school ends, the two brothers' lives take different directions, because Udayan decides not to settle down in the West. He stays in India, teaching science in a technical high school while "a high tide of revolution was sweeping through the world" (33) and the Communist Party of India, Marxist-Leninist in its ideology, the CPI(ML), is officially set up in 1969. Udayan's rebellious desires are backed up by Gauri, his future wife. They meet during the Calcutta demonstrations in solidarity with the uprising in Naxalbari, sharing the same dream of visiting Indian rural areas in order to improve the precarious conditions of agricultural labourers. Jhumpa Lahiri weaves the relationship between Udayan and Gauri with the expansion of the Naxal guerrilla: "they ransacked schools and colleges across the city. In the middle of the night they burned records and defaced portraits, rising red flags. They plastered Calcutta with images of Mao" (88).

Udayan's brutal death, which is the turning point of the novel, is gradually revealed by the perspectives of the characters involved: Subhash, Udayan himself, their mother Bijoli, and Gauri. In spite of the third person omniscient narrator, events tend to be continuously reshaped by the viewpoints of the characters. When Subhash returns to Calcutta for Udayan's funeral, he is informed by Gauri that one morning soldiers started to search for his brother. Udayan, who was hiding under the floodwater of the lowland, underneath the water hyacinths that used to grow there, was finally found out and shot to death. The soldiers drove away with his corpse which was never returned to his family. Then, Subhash marries Gauri, who is pregnant with Udayan's child, and takes her to Rhode Island to start a life anew. Here, Lahiri zooms in on their personal stories: Bela is brought up without being told of her natural father and one day Gauri decides to abandon her daughter and Subhash for her academic career.

When portraying the Naxal movement, Lahiri combines the authorial voice with personal viewpoints. As she points out in the "Acknowledgments" of the novel, Lahiri has drawn on a series of sources to understand the Naxalite movement, such as books, websites and personal memories. In The Lowland, the Bengali-American writer refers to the words of political leaders (Kanu Sanyal and Charu Majumdar) and to their official declarations taken from journals:

By the year 2000, that is only thirty-one years away from now, the people of the whole world will be liberated from all kinds of exploitation of man by man and will celebrate the worldwide victory of Marxism, Leninism, Mao Tse-tung's thought. ${ }^{3}$ (33)

The authorial voice alternates with subjective recollections. Bijoli mourns Udayan above the "lowland" where he was killed. A memorial tablet records the violent assassination, but the place itself is an emblem of conflict and massacre. For Bijoli, the lowland is a site where personal and historical traumas blur. The marshy field reminds her of the most traumatic episode of Indian postcolonial history: the 1947 Partition. She can still recall the images of refugees migrating in search of food in the ponds near her house "eating insects, eating soil, eating grubs that crawled in the ground" (187).

The landscape of the lowland is invested with symbolic meaning and it can be read as an allegorical archive which preserves memories of historical and personal impor-

3. This quote is part of Sanyal's declaration on May Day 1969 when the CPI (ML) was founded. Kanu Sanyal (19322010) was the chairman of the CPI (ML), while Charu Majumdar (1918-1972) was the general secretary of the party. 
tance. Filling up with monsoon rains, the two ponds are an allegorical portrayal of the two brothers. Insomuch as the lowland tends to be remoulded by the changeable weather conditions, it generates different forms of life: flowers, weeds, and eggs become emblems of an abiding resistance against the hostile weather. In this marshland, "certain creatures [...] survived by burying themselves in mud, simulating death, waiting for the return of the rain" (3). At a symbolic level, Udayan, who was hiding in the lowland before his assassination, buries his eggs (Bela) which will hatch thanks to Subhash's care. The brotherly tie and the fragments of the past, therefore, are located in nature and the novel is structured around the recurrent imagery of burial and re-emergence. Bijoli's attempt to remove objects and garbage around Udayan's memorial, in spite of the derision of her neighbours, conveys her concern with the need to unveil the truth about her son's death. In a similar vein, Subhash, who studies the "sediments that oxidize at low tide," (43) tries to understand how memory works. The sediments on the estuaries of the Rhode Island, which solidify the landscape, are perceived as a hindrance by Subhash, who is striving to retain the fragments of his own identity. The "black stains on the sand," (43) instead, epitomize the fractured ties with his homeland since the American marine environment reminds him of the Bengali lowland. Through the convergence of the Indian and American natural landscapes, Lahiri describes the attempts of a cultural accommodation of American society without obliterating one's own ethnic roots. She seems to confirm the idea that the natural archive "is a location of knowledge, a place where history itself is housed, where the past is accommodated" (Boulter 3).

With Udayan's death, the Naxal insurgencies gradually disappear and the narrative switches from the suburban areas of Calcutta to the marshy coastline of Rhode Island. The political chaos and the events that surrounded Udayan's death are finally disclosed towards the end of the novel when Gauri decides to see Bela after nearly twenty-five years. Readers are told of the suicide of Kanu Sanyal in 2010, while American newspapers report the upsurge in the Naxal guerrilla: "Maoist insurgent blowing up trucks and trains. Setting fire to police camps. Fighting corporations in India. Plotting to overthrow the government all over again” (275). In a sudden epiphany, Gauri recollects all the things Udayan used to ask her during the 1967 Naxal riots. Readers learn that Gauri had indirectly provided information about a policeman who had been killed by Udayan. Gauri, hence, was acting as a spy for the Naxalites and she bears a responsibility in the assassination, though unintentional. Even if Gauri avoids the same fate as Udayan, she is not left unpunished. When she meets her daughter, who is an adult woman and has become a mother, Gauri is denied Bela's affection and she realizes the emptiness with which she has filled all her existence.

Whereas Lahiri is "unambiguous in her condemnation of the violence carried out by both the state and its guerrilla opponents" (Martyris 42), she remains detached from historical processes and the brutality of their violence. Udayan's sudden death makes space in the novel for the affectionate and psychological dimension of human suffering. The narrative abandons the reportage mode about the violent upheavals in West Bengal and it shifts the focus to the individual and isolated lives of Subhash, Gauri and Bela in the United States. The epic and political tone is replaced by subjective insights on the alienation of diasporic existences, particularly through the perspective of Bela. The dialogue between the lowland in Calcutta and the swampy coastline in Rhode Island 
opens up an imaginative revision of the personal and historical tangle narrated in the novel. In line with Slemon, who sees postcolonial allegory as a solution that "opens up to imaginative revision," (Slemon 165) Lahiri invests the natural landscape with a transformative power: the lowland becomes a metaphor through which collective and individual history comes to be rewritten. Bela's ultimate ecocritical stance ${ }^{4}$ represents the conclusive step of her family saga, in search of a cultural collocation in the United States with nostalgic echoes of Bengali history and space.

\section{"Gorkhaland for Gorkhas": Conflicts and Melancholia in Kiran Desai's The Inheritance of Loss}

Kiran Desai's novel was awarded the Booker Prize in 2006, the same prize for which The Lowland was shortlisted in 2013. In The Inheritance of Loss, Desai describes insurgencies dating back to the long shadow of Partition. One of the characters in the novel claims that Partition was the first big mistake which allowed for the emergence of separate countries and ongoing smaller divisions, a "first heart-attack to our country that has never been healed" (129). Like in Lahiri's novel, the plot of The Inheritance of Loss shuttles between India and the United States, revolving around the memories of an old former judge, named Patel, who was educated in Cambridge. Patel lives in a house in Kalimpong, North India, with a view over the Himalayas. The judge shares the house with his cook and with Sai, his westernized Indian granddaughter who is addicted to English novels and has a crush on Gyan, her Muslim-Nepalese mathematics tutor ${ }^{5}$. The American side of the novel narrates the illegal immigration of Biju, the son of Patel's cook, who is on the run from the immigration authorities and lives in slum areas. The novel is set in the mid-1980s, during the agitation for Gorkhaland in the north-eastern hills of Darjeeling, close to the border with Nepal. The narrative, however, moves back and forth at a temporal and geographical level, from colonial India to present-day globalized New York. Between cultural differences and historical events, the characters negotiate with a state of non-identity. They are all "inheritors of loss" since they bear the signs of a (post)colonial legacy which is difficult to leave behind even when trying to assimilate into another culture.

Historically, the area around Darjeeling had been run by the Gorkhas, an ethnic and linguistic enclave between the territories of Nepal and West Bengal. With the treaty of Sugauli, which signed the end of the Anglo-Nepalese War (1814-1816), these lands were passed to the East Indian Company and Darjeeling was annexed into the British Indian Empire. Nevertheless, when India became independent in 1947, the population of the area felt betrayed and neglected:

In April of 1947, the Communist Party of India demanded a Gorkhasthan, but the request was ignored. [...] We are laborers on the tea plantations, coolies dragging heavy loads, soldiers. And are we allowed to become doctors and government workers, owners of the tea plantations? No! We are kept at the level of servants. (167)

4. As a girl, Bela majors in environmental science and finds a job in a farm. She recycles waste and eats local food, denouncing the unequal distribution of wealth in the world. At the end of the novel, Bela meets an American divorcee and she moves to his farm where she seeds vegetables and breeds sheep and hens along the Atlantic Ocean. Bela's ecocritical attitude encompasses a critique of neoliberal economy in a place that, with its marshlands, is a reminder of the lowlands in Calcutta.

5. Kiran Desai seems to be drawing on her mother's novel Fire on the Mountain (1977). In Anita Desai's novel, Nanda Kaul's happy and isolated life comes to be threatened by the arrival of his granddaughter Rakka. 
Gyan's ancestors, for instance, leave their birthplace in Nepal. They move to Darjeeling with the promise of working in a tea plantation, but all the money they invest produces no result. The character of Gyan echoes Udayan in The Lowland. Reflecting on the historical hardships and financial difficulties of Indian-Nepalese people, Gyan embraces the Gorkha National Liberation Front (GNLF), a political militarized group whose main aim is to create a separate Gorkha state in the Nepali-speaking area. Desai's focus on the GNLF and on the riots that wreaked havoc in North India between 1986 and 1988 illustrates the disastrous outcomes of ethnic oppression. Not only is Gyan frustrated by the awareness that Nepalis have always been exploited, first by the British Empire and later by the Indian middle class elite. Coming from an extremely poor family, he also feels ashamed of Sai and the judge's Anglophilia and their bourgeois environment makes him vindictive.

The novel opens with the arrival at the judge's house of three armed Nepalese men who, under Gyan's instructions, are seeking guns. The insurgents in Desai's novel are constantly described as young people who have turned to violence for adventure. They are ironically described as wearing "leather jackets from the Kathmandu black market, khaki pants, bandanas - universal guerilla fashion," (4) and they force the judge and Sai to repeat their motto: "Gorkhaland for Gorkhas" (7). Nevertheless, Gyan, who had always thought of moving to Australia or the United States in order to be "free from history," has doubts about his commitment to the ethnic fervor of such a "compelling pull of history" (160):

The patriotism was false, he suddenly felt as he marched; it was surely just frustration the leaders harnessing the natural irritations and disdain of adolescence for cynical ends; for their own hope in attaining the same power as government officials held now, the same ability to award local businessmen deals in exchange for bribes, for the ability to give jobs to their relatives, places to their children in schools, cooking gas connections. (157)

Through Gyan's viewpoint, Desai points out the double face of globalization: on the one hand, it tends to awaken a sense of identity in ethnic minorities but, on the other, it seems to claim that cultural essentialism is doomed to failure since, with the disruption of nation-states and the emergence of free market and liberal capitalism, identities cannot be fixed. As Gyan ironically observes, the same Gorkha insurgents seem to retain neo-imperial signs in the clothes they wear: "Did they see themselves from a perspective beyond this moment, these unleashed Bruce Lee fans in their American T-shirts madein-China coming-in-via-Kathmandu?" (157). Desai's treatment of the GNLF "reaffirms the continued dependence of postcolonial national formations on imperial structures" (Ashcroft 44). The demonstrators block food circulation, vandalize houses, burn down governmental offices and hamper the circulation on roads. Yet, through the voice of secondary anglicized characters, Desai blames politicians and legislative authority:

[...] this state making, the biggest mistake that fool Nehru made. Under his rules any group of idiots can stand up demanding a new state and get it, too. It all started with Sikkim. The Neps played such a dirty trick and began to get grand ideas - now they think they can do the same thing again. (127)

The Gorkhas' controversial request for independence is additionally complicated by Desai's portrayal of the natural landscape that surrounds Kalimpong. The incipit of the novel describes a mist "charging down like a dragon, dissolving, undoing, making 
ridiculous the drawing of borders" (9). The mist ironically displays the irrational logic of military activities in a land that "had always been a messy map" (9). Kalimpong, therefore, embodies the novel's preoccupation with struggles about borders and identity. Like "shadow lines" (Ghosh), boundaries are sites of warring, upheaval and mobility. Not only does the mist cover and blur the borders of the region, it also seems to mock confines. The mist can be interpreted as a sign of resilience against the lines drawn by humans. It dissolves borders, turning solid objects into fluid and changeable entities, to such an extent that "nothing remained that did not seem molded from or inspired by it" (9). Such a hazy picture conveys a sense of hybridity which allegorically reframes postcolonial conflicts and territorial reconfigurations. The GNLF attempts to draw new lines on a territory which had already been colonized by the British are contrasted by a lush and heterogeneous landscape which seems to elude monolithic confinement.

The Inheritance of Loss, however, ends on a positive note. Whereas the incipit describes the sublime beauty of a dusky mist over the Himalaya, ${ }^{6}$ the conclusion stages the reunion of Biju with his father under the eyes of Sai, while "the five peaks of Kanchenjunga turned golden with the kind of luminous light that made you feel, if briefly, that truth was apparent. All you needed to do was to reach out and pluck it" (324). The novel ultimately echoes its epigraph, Jorge Luis Borges' poem "Boast of Quietness." The poem speaks of those who migrate and dwell in between cultures and territories and of the tensions and frictions which arouse from the need to belong to a place. By satirizing the Nepalis' map-making struggles, Desai ultimately opens up to cosmopolitan directions. The novel is a testimony to the sense of alienation and loss which permeate our globalized world. The realist mode of the narrative and the psychological insights into the lives of its expatriate characters capture the vulnerability of modern humanity in a world fractured by inequalities and territories of conflictual historical legacy.

\section{Trauma and Territorial Struggles in Anita Rau Badami's Can You Hear the Nightbird Call?}

The time period explored by the novels analyzed so far (1960s-1980s) featured further critical moments in Indian history, such as the Emergency and the riots and upheavals which followed in its aftermath. One of the most controversial periods of post-Partition India, the Emergency, was a state of dictatorial rule, from 1975 to 1977, when Prime Minister Indira Gandhi imprisoned political opponents and repressed civil rights and free thought. ${ }^{7}$ Parts of Midnight's Children depict the authoritarian turn of Indira Gandhi's political agenda. The same upheaval is portrayed in Mistry's A Fine Balance, where the program of making cities beautiful and livable justifies the aggressive demolition of Bombay's slum areas, while a strict family planning policy makes vasectomy an ordinary practice among the less well-off. Between personal and political dynamics, Anita Rau Badami's third novel, Can You Hear the Nightbird Call? (2006), explores the Emergency, underscoring the positive and negative aspects of the 1975-1977 period. The title of the novel derives from the ghost-story of a monstrous four-winged bird whose singing is supposed to make people mad. The title, therefore, epitomizes the

6. Desai's first novel, Hullabaloo in the Guava Orchard (1998), is also set in the Himalayas.

7. Invoking article 352 of the Indian Constitution, which gave her extraordinary powers, Mrs. Gandhi opposed the Court's verdict, which had declared her election null and void, and she imposed the state of Emergency in the country. 
sense of deep loss and it is a metaphor for the haunting evil which affects people and territories in the Indian subcontinent. The allegory of the eerie bird-singing foreshadows the brutal conflicts which permeate the novel.

The narrative begins in the pre-Partition era and it ends with the explosion of Air India flight 182 off the coast of Ireland in 1985. The plot spans the story of three women, Bibi-ji, Leela and Nimmo, between Punjab and Canada. Despite their different religious beliefs, the three women are emblems of a female community which tries to resist the atrocities of terrorism through affect and solidarity, while violence constantly recurs in the novel with the events of the two Indo-Pakistani wars $(1965 ; 1971),{ }^{8}$ the Khalistan movement (1970s and 1980s), ${ }^{9}$ the Emergency, the assassination of Indira Gandhi and the subsequent anti-Sikh riots.

Can You Hear the Nightbird Call? addresses the silences of a conflictual past from the transnational perspective of an Indian-Canadian writer. Revolving particularly around the Sikh community, Badami touches on the problematic situation of living in India during the Emergency. In a period marked by the suspension of constitutional rights, interrogations, imprisonments and slaughter of people, one character ironically observing: "you are so happy that everything is on time, but don't care that some poor innocents are sitting in jail for reasons not known to them? What if it happens to one of you? Or to your sons or daughters?” (274) While students who protest against Gandhi's resolutions mysteriously disappear, the repercussions of the religious and territorial conflicts are discussed in "The Delhi Junction Café," the restaurant run by Bibi-ji and her husband in Vancouver. This place becomes the site where ethnic roots and transnational routes converge. With its "lithographic prints of the ten Sikh Gurus, [...] the painting of the Golden Temple, [...] pictures of Nehru, Gandhi, Marilyn Monroe [...] and the clocks displaying the time in India, Pakistan, Vancouver, England and New York," (Badami 59-61) "The Delhi Junction Café" functions as a transnational area of contact between religious faiths and ethnic origins. Yet, this contact-zone comes to encompass the dynamics of class, gender, race and religion and the communal violence which undermines these differences is reflected in the Canadian restaurant.

Communal violence, with its repetitions and re-emergences, crosses the Indian borders, creating a space of instability and contestation. While some characters can see benefits in the Emergency, such as socio-economical improvements (measures to keep prices down, distribution of land, reduction in rates of tax evasion), others, instead, condemn the irrational measures of a political dictatorship. Chapter 18, entitled "A State of Emergency," opens on a New Delhi August morning, shuttered by the monsoon rains, where trains run on time and people are thrown into jails. Badami depicts the controversial effects of the Emergency: while upper classes support the efficiency reflected in trains running on time or employees being punctual, the poor and vulnerable sections of society suffer from persecutions and authoritarian arrests.

Badami's omniscient narrator not only alternates between Punjab and Canada. The narrative perspective tends also to accommodate the various viewpoints. Badami employs interspersed narrative voices which combine separatism with moderation and to-

8. The two conflicts between India and Pakistan led to a further small Partition in Pakistan. East Pakistan became independent and it was named Bangladesh at the end of the 1971 Liberation War.

9. The movement was a Sikh nationalist organization whose main objective was the creation of a new country mainly carved out of Punjab, the traditional homeland to Sikhs. 
lerance. Dr. Randhawa, for instance, embodies the militant rhetoric of the Khalistan movement. His words are meant to incite violence and rebellion, clearly stating the sense of discrimination felt by the Sikh who see themselves as treated differently than Hindus or Muslims:

The Sikhs have been betrayed! We have been betrayed for two hundred years - first by the British, who stole Punjab that our great Maharaja Ranjit Singh won for us from the Mughals and then by the Congress Brahmans, who gave the Musalmans their Pakistan and the Hindus their India but left the Sikhs to die in between; then by Nehru and his winning words. And we have been cheated again by the rose-wearing Brahman's daughter, Indira Gandhi who takes the wheat that we grow on our lands and distributes it to all of Hindustan, who diverts the water from our rivers to neighboring states and leaves us with empty buckets. (252)

Dr. Randhawa's rhetoric entails the centrality of territory as a means for ethnic identification. He supports the idea of a separate state for the Sikhs as a result of a victimization that he portrays with images of territorial exploitation and reconfiguration which have ruined the very resources of the land.

With "Operation Blue Star," the novel reaches the final stage of the growing hostility between Sikh rebels and the Indian government. The Indian soldiers violate the Golden Temple in Amritsar, where militants of "All India Sikh Students Federation" were hiding weapons and ammunition, killing pilgrims, rebels and innocent bystanders. The ensuing violence culminates in the assassination of Mrs. Gandhi by her two Sikh bodyguards in October 1984. Mimmo and her family are destroyed by the violent escalation, while Bibi-ji, who is Sikh, ultimately cuts off her lifelong friendship with Leela, who is Hindu.

The novel ends with the explosion of Air India Flight 182 in June 1985, supposed Sikh terrorist revenge against Hindu aggressions. In its mortal significance, this episode symbolically connects India with Canada, since the majority of the victims were Canadian citizens. Anita Rau Badami, in conclusion, poignantly describes how conflictual historical events have shaped contemporary Indian territories. Either grounded in ethnic differences or religious ones, tensions and disputes over borders inexorably affect the lives of ordinary and marginal people. As Badami observes in the "Historical Note" which closes her novel, history "forms the backdrop" (410) of the narrative. In spite of the rhetoric of violence, Badami offers a critique of religious fundamentalism and separatism with wisdom and hybrid existence. The novel, however, crosses historical traumas and conjures up images of displacement and women's attempts to counterbalance the ensuing violence. The idea of connection that Badami weaves between India and Canada is meant to condemn violence and divisions. The cultural and fragmented memories that intersect the narrative level of the novel foreground a transnational ethics that resists oppression and violence.

\section{Conclusion}

Writers such as Lahiri, Desai, and Badami are Indian transnational writers whose works revolve around traumatic experiences and violent events in their country of origin. In the realistic portrayal of territorial conflicts, their narratives are shaped by a historical realism which blends allegory (the ponds, the mist, the bird's song) with ethnic and political tensions on a local and global scale. These novels function as instruments of 
knowledge production insomuch that they depict images of violence which "fissure the imagined community and [...] become sites of contestation" (Dalley 10).

By staging "sites of contestation," contemporary Indian writing in English underscores its relevant ethical function. The ethical politics of the transnational novel is embedded in its attempt to highlight a sense of solidarity and human connection built on a common history of oppression and marginalization. As Nayar points out, the "transnational parasite" is ethical insomuch as it provides a response to the collective and individual traumas which "exceed the territorial limitations of the nation state" (Nayar 31). The encounter with the vulnerability of oppressed and marginalized subjects discloses an ethical trajectory marked by hybridity and connection which Leela Ghandi defines as a postnational "ethics of hybridity" (Gandhi 140). By blurring the boundaries with the "other," this ethical stance creates a "postnational utopia" (Gandhi 140) which recalls Ashcroft's utopian search of a "home in the world" (Ashcroft 38).

Angelo Monaco

University of Pisa, Italy

\section{Works Cited}

Ashcroft, Bill. "Re-writing India." Sen and Roy 29-46.

Badami, Anita Rau. Can You Hear the Nightbird Call? New Delhi: Penguin, 2006.

Boulter, Johnathan. Melancholy and the Archive. Trauma, History and Memory in the Contemporary Novel. London and New York: Continuum, 2011.

Butalia, Urvashi. Partition: The Long Shadow. London: Penguin, 2015.

Dalley, Hamish. The Postcolonial Historical Novel: Realism, Allegory, and the Representation of Contested Pasts. London: Palgrave Macmillan, 2014.

Dasgupta, Biplab. "Naxalite Armed Struggles and the Annihilation Campaign in Rural Areas." Economic and Political Weekly (February 1973): 173-88.

DesAi, Kiran. The Inheritance of Loss. New York: Atlantic, 2006.

—. Hullabaloo inthe Guava Orchard. 1998. London: Faber \& Faber, 2014.

GHosh, Amitav. The Shadow Lines. 1988. Boston: Mariner, 2005.

GHANDI, Leela. Postcolonial Theory: A Critical Introduction. New York: Columbia UP, 1998.

LAHIRI, Jhumpa. The Lowland. London: Bloomsbury, 2013.

Martyris, Nina. “The Naxal Novel.” Dissent 61.4 (Fall 2014): 38-44.

Mistry, Rohinton. A Fine Balance. 1995. New York: Knopf Doubleday, 2010.

NAYAR, Pramod K. "The Transnational Indian Novel in English: Cultural Parasites and Postcolonial Praxis." Imagined Identities: Identity Formations in the Age of Globalization. Ed. Gonul Pultar. Syracuse: Syracuse UP, 2014. 17-32.

Rothstein, Mervyn. "India's Post-Rushdie Generation: Young Writers Leave Magic Realism and

Look at Reality." The New York Times. 30 July 2015 <http://www.nytimes.com/2000/07/03/books/ india-s-post-rushdie-generation-young-writers-leave-magic-realism-look-reality.html>.

Roy, Arundhati. The God of Small Things. 1997. New Delhi: Penguin, 2008.

Rushdie, Salman. Midnight's Children. 1981. New York: Penguin, 2006.

SEN Krishna, and Rituparna Roy, eds. Writing India Anew: Indian English Fiction 2000-2010. Amsterdam: Amsterdam UP, 2014.

Stemon, Stephen. "Postcolonial Allegory and the Transformation of History." Journal of Commonwealth Literature 23.1 (1988): 157-68. 